\title{
NEMI ARÁNYOK ÉS A ROKONSZENVI VÁLASZTÁSOK KAPCSOLATÁNAK VIZSGÁLATA ENYHÉN ÉRTELMI FOGYATÉKOS TANULÓKAT INTEGRÁLÓ OSZTÁLYOKBAN
}

\author{
Szerzők: \\ Herbainé Szekeres Erika \\ Pest Megyei Pedagógiai Szakszolgálat \\ Gödöllői Tagintézménye \\ Szekeres Ágota \\ Eötvös Lóránd Tudományegyetem
}

Lektorok:

Mesterházi Zsuzsa

Eötvös Loránd Tudományegyetem

Papp Gabriella

Eötvös Loránd Tudományegyetem

Mező Ferenc

Debreceni Egyetem

Első szerző e-mail címe:

szekereseri@gmail.com
Nemes Magdolna

Debreceni Egyetem

Herbainé Szekeres Erika és Szekeres Ágota (2016): Nemi arányok és a rokonszenvi választások kapcsolatának vizsgálata enyhén értelmi fogyatékos tanulókat integráló osztályokban. Különleges Bánásmód, II. évf. 2016/3. szám, 51-66. DOI 10.18458/KB.2016.3.51

\begin{abstract}
Absztrakt
Tanulmányunkban enyhén értelmi fogyatékos gyermekeket integráló osztályközösségek állnak a középpontban.

A vizsgálati mintát négy 20 föböl álló osztály alkotta, melyek közül kettöben fiúk voltak többen, és az egyikben fiú, a másikban lány volt az integrált tanuló. A másik két közösségben a lányok képviselték a többséget, egy-egy fiú, illetve lány fogyatékos diákkal közöttük. Célunk a közösségek nemi arányainak és a rokonszenvi választások összefüggésének megfigyelése volt. Ennek érdekében minöségi fókuszú elemzést végeztünk. Módszerül a szociometriát alkalmaztuk, az adatok feldolgozása pedig a Smetry szoftverrel történt.

Eredményeink közül kiemeljük, hogy a vizsgált közösségekben a nem viszonzott rokonszenvi választások közül az azonos nemek közöttiek voltak nagyobb számban, illetve az azonos vagy „,közeli” szociometriai státuszú társ felöl érkezö kapcsolódási igény több esetben realizálódott a tanulók között. Az utolsó feltételezésünk - lány többségü osztályokban rosszabb a lányok pozíciója, különösen, ha integráltak - relevanciáját jól látható eredmények bizonyították. Abban az osztályban lett a legkedvezötlenebb a lányok szociometriai helyzete, ahol ök képviselik a többséget és az integrált tanuló is lány.
\end{abstract}

Kulcsszavak: integráció, szociometria, enyhe értelmi fogyatékosság

Diszciplina: gyógypedagógia, pszichológia, neveléstudomány 


\section{Abstract \\ RESEARCH OF CONNECTIONS BETWEEN GENDER RATIOS AND CHOICES BASED \\ ON FELLOW FEELING IN CLASSES INTEGRATING MILD INTELLECTUAL DISABILITY CHILDREN}

In our study the main focus has been on class communities integrating children with mild intellectual disabilities.

The sample examined involved four classes, each consisting of 20 students, two of which had more boys than girls, and one had an integrated boy, while the other had an integrated girl. In the other two communities girls were the majority, with one boy and one girl integrated in them respectively. Our aim was to observe the correlation of gender proportions and the choices of likes and dislikes. Therefore a quality focused analysis has been performed. Sociometry has been applied as a method and data analysis has been carried out by the Smetry software.

Among our results we would like to highlight that the non-reciprocal choices of likes and dislikes are more frequent in between the same gender and the need to connect with a classmate of the same or „similar” sociometric status has been realized among the students several times. The relevancy of our last supposition - that within the classes with a female majority the status of girls is worse especially if they are integrated - has been proven by striking results. The sociometric status of girls has been the least favourable in classes where the majority and the integrated student are also girls.

Keywords: integration, sociometry, mild intellectual disability

Disciplines: special education, psychology, education

\section{Kapcsolatok alakulása integráló közösségekben}

Tanulmányunkban enyhén értelmi fogyatékos tanulók integrált osztályban elfoglalt helyét, kapcsolataiknak jellemzőit szeretnénk megismerni. Mivel az enyhe értelmi fogyatékosság sok esetben nem nyilvánvaló, mert például a tanulóknak nincsen látható fizikai mássága, vagy bizonyos feladatmegoldások során jól is tudnak teljesíteni, így a tanulás, a játék és az interperszonális kommunikáció esetén nincs mire támaszkodniuk a többségi tanulóknak. Ez megnehezíti a kapcsolatok kialakítását és fenntartását. Az integrált tanuló oldaláról a barátságok, de akár kapcsolatok kialakításának gátja lehet a kölcsönösség hiánya vagy éppen a szabadidős tevékenységek megosztásának nehézsége (Schneider, 2016). Azok a tanulók, akiknek a fogyatékossága kevésbé látható, nagyobb szociális támogatást igényelnek a kapcsolatok kialakítása érdekében azoknál, akiknek nyilvánvalóbb szükségleteik vannak (Tuersley-Dixon, Frederickson, 2016).

Papoutsaki, Gena és Kalyva (2013) magányos enyhén értelmi fogyatékos gyermekeket (714 évesek, 93 fiú és 61 lány) kérdezett meg az elutasítottságukról. A megkérdezett 154 tanuló 4 okot említett, ami miatt szerintük ők izolálódtak a többiektől: interperszonális kapcsolatteremtési nehézség, társakkal való kapcsolódási lehetőségek alacsony száma, fizikai megjelenésük és egyéb okok, amiket nem tudtak megindokolni.

A vizsgálatban szereplő tanulók 51\%-a nem érzett magányt, 25\%-uk azonban érzett magányt és kirekesztettséget is. A fiúk kevesebb magányosságérzésről számoltak be, mint a lányok. Ezt magyarázhatja, hogy a fiúk több fizikai aktivitást igénylő játékot játszanak (pl: foci), ami nem követel kognitív vagy interperszonális képességeket és nincsenek nagyon szigorú szabályok. Ezzel szemben a lányok páros és zárt interperszonális viszonyokat alakítanak ki, ami fejlettebb kognitív képességeket feltételez. Ez az enyhén értelmi fogyatékos 
lányoknál hiányozhat. Az is lehetséges, hogy a fiúk könnyebben nevezik barátjuknak egy-egy társukat, mert a viszonyaik kevésbé komplikáltak.

Szintén a magányosság vizsgálata állt a középpontban Gilmore és Cuskelly (2014) tanulmányában. Azt találták, hogy az értelmi fogyatékos személyek közel fele krónikusan magányos, míg a tipikus populációban ez az arány 15-30\% között mozog. Az értelmi fogyatékos személyeknél található készségdeficitek - amelyek érintik a kommunikációt, az önszabályozást és a szociális megértést - korlátozhatják a kapcsolatok kialakítását. Ez természetesen visszafelé is hat, hiszen ezek a korlátozott lehetőségek "megvédik" ezeket a deficiteket és megerősítik a negatív attitüdöt az értelmi fogyatékos személyekről.

Egy másik vizsgálatban azt találták, hogy a sajátos nevelési igényü tanulók (akiknek a 70\%a enyhén értelmi fogyatékos volt) integrált osztályokban inkább magányosak, negatívabb az énképük, és a tanárok úgy ítélik meg, hogy gyengébbek a szociális képességeik és több problémás viselkedést mutatnak, mint a nem sajátos nevelési igényü társaik. Mivel szignifikáns pozitív korrelációt találtak a sajátos nevelési igényü diákok énképe és szociális képességei között ezért úgy látják, hogy a szociális képességek fejlesztése pozitívan hathat az énképre, ami segíthet pozitívabb szociális kapcsolatokat kiépíteni a kortársakkal és csökkentheti a magányosság érzését is (Kucukera és Tekinarslanb, 2015). Az énkép fontosságát hangsúlyozza Pijl és Frostad (2010) is.

Nieuwenhuijzen és munkatársai (2004) igazolták, hogy összefüggés van az értelmi fogyatékosság, a szociális információ feldolgozás és a viselkedési problémák között. A 10-14 éves (56 értelmi fogyatékos, 31 ép) gyermekeknek videofelvételek alapján kellett szociális információ - feldolgozó feladatokat megoldaniuk. A fogyatékos gyermekek többféle negatív elemet kódoltak, mint ép társaik. Viszont válaszaik között kevesebb megerősítő válasz volt és ezeket kevésbé pozitívnak ítélték meg. Amikor megerősítő válaszokat kínáltak nekik, akkor pedig kevesebbet választottak belöle. A fogyatékos gyermekek többször adtak alárendelö reakciót és az alárendelő reakciót pozitívabban értékelték. Magabiztosabban reagáltak a fogyatékos társaik videóbeli reakcióira, mint ép társaikéra. Úgy tünik, számukra az alárendelődő viselkedés válik be a mindennapokban a kortárs közösségben.

A barátságok kialakítására és fenntartására fontosak a tudatelméleti készségek is, hiszen ezek meghatározhatják, hogy egy értelmi fogyatékos tanuló mennyire érzi úgy, hogy őt a többiek elfogadják (Fiasse és Nader-Grosbois, 2012).

Az sem mindegy, hogy egy integráló közösségben milyen tanulásszervezési eljárásokat használ a pedagógus, hiszen a kooperáló, együttmüködő tanulási struktúrákat használó osztályokban az értelmi fogyatékos tanulókat jobban elfogadják az osztálytársak, mint a versengő légkörben (Piercy, Wilton és Towsend, 2002).

\section{Nemi különbségek}

Barátságok, kapcsolatok kialakításában nagyon másként kezdeményeznek a fiúk és a lányok. Lányoknál jellemzőbb a kooperatív interakció, a kérés kifejezése. A fiúk csoportjaiban az erőteljesebb, durvább játékok, a dominancia megszerzésére irányuló törekvés, a parancsoló magatartás és a korlátozó interakciók tapasztalhatóak (L. L. Anh, 2004).

Amikor egy csoportba kerülnek a fiúk és a lányok, mindkét nem a rá jellemző érintkezési stílust képviseli, így e két stílusnak a találkozása a fiúk dominanciáját és a lányok alárendelődését eredményezi (L. L. Anh, 2004; F. Lassú, 2004). A tanteremben elvárt viselkedés jobban megfelel a lányoknak.

Serdülőkor előtt a gyerekek barát - és szimpátiaválasztásai szinte kizárólag az azonos nemü gyerekekre vonatkoznak. A nemek szerinti elkülönülés azonban a fiúknál általában erősebb, mint a lányoknál. A lányok barátkozási stílusa intenzív, a fiúké extenzív. A lányok csoportjai kisebbek, általában 2-3 barátnőből állnak (F. Lassú, 2015). Azok a lányok, akik számára 
fontos a kortársakkal való kapcsolat, a legjobb barátnő(kk)vel való együttlétet, míg az intenzív szociális érdeklődésű fiúk a barátok egy csoportjával való együttlétet részesítik elönyben (Vajda, 2004). A lányok páros csoportjai kevésbé, míg a fiúk páros csoportjai nyitottak új tagok befogadására. Edleson (1980) 4., 5., 6. random kiválasztott osztályok tanulói (441 fiú 455 lány) körében végzett vizsgálatában szociometriai rangsorolást alkalmazva azt találta, hogy az ugyanolyan nemü választások jelentősen magasabbak, mint az ellenkező nemü választások. Hasonló eredményt kapott F. Lassú (2015), aki felnőtt nők visszaemlékezései alapján megállapította, hogy az interjút adó nők többsége azonos nemü barátot választott legjobb barátnak.

Kutatók arra hívták fel a figyelmet, hogy ha a fiúk és a lányok nem az ellentétes nemmel versengenek, hanem lányok a lányokkal és fiúk a fiúkkal (azonos nemúekkel), akkor a lányok sokkal kevésbé együttmüködőek, mint a fiúk (Argyle, 1991 idézi Fülöp, 2004). Általában mind a fiúk, mind a lányok az azonos nemúeket tekintik természetes riválisnak, és csak másodsorban jelennek meg a másnemüek (Fülöp, 2004).

Fogyatékos tanulók esetében nem teljesen egyértelmüek az adatok arra nézve, hogy a sajátos nevelési igényü fiúknak vagy lányoknak könnyebb vagy sikeresebb a kortársakkal való kapcsolat kialakítása. Egy hazai vizsgálatban azt találtuk, hogy az integráltan tanuló enyhén értelmi fogyatékos gyermekek szociálisan hasonló módon illeszkednek be, mint a nem fogyatékos fiúk. A lányoknál már ugyanez nem mondható el - a nem fogyatékos lányoknak több barátjuk van az osztályban, mint az integráltan tanuló, enyhén értelmi fogyatékos lányoknak (Szekeres, 2011a; Szekeres 2011b). Hasonló eredményt kaptak Bakker és tsai (2007), akik szerint a fiúk és a lányok megítélése eltérő az osztálytársak körében; amíg a fiúk megítélése független a teljesítménytől és a diagnosztikai kategóriától, addig a lányoké nem az utóbbiak így kevésbé kerülnek be a népszerü csoportba és inkább elutasított szerepben vannak az osztályban. Mand (2007) eredményei a fentieknek ellentmondanak, a fiúk mind szegregált, mind integrált közegben inkább kirekesztődtek, mint a lányok. Ezt erősíti meg Grüning (2012) kutatása is, aki azt találta, hogy a lányok beilleszkedése sikeresebb, például a szünetben aktívabbak, mint az integráltan tanuló fiúk; elégedettebbek tanulmányi eredményeikkel a nehézségek ellenére is.

Baydik és Bakkaloglu (2009) szerint a sajátos nevelési igényű tanulók esetében a tanulmányi kompetencia és a fizikai megjelenés előrejelzi a szociális elfogadottságot, míg az el nem fogadottságot a viselkedési probléma jelzi elöre. Így a lányok kevésbé sikeres beilleszkedése mögött állhat akár az is, hogy az enyhén értelmi fogyatékos lányok külső megjelenése nem olyan szerencsés, mint a többségi gyermekeké.

$\mathrm{Az}$ integráció sikerességét itthon a lányok esetében a pedagógusok jobbnak látják, de a gyógypedagógusok még náluk is jobbnak ítélik meg. Ez ellentétes a gyermekek önbevallásával (Szekeres, 2011b), valamint a szociometriai kikérdezés eredményeivel is (Szekeres, 2012). A valós észleleteket torzíthatják a sztereotipikus hiedelmek. Ezek szerint a fiúk inkább kompetensek és viselkedési problémákkal küzdenek, míg a lányok szociálisabbak és jobban tudnak alkalmazkodni (Szabó és tsai, 2014). Ezért tartjuk fontosnak a fogyatékos tanulók esetében is "az egyes tanulók nemi sztereotípiáktól független egyéni percepcióját és értékelését” (Kovács, 2014, 49. o.)

\section{Hipotézisek}

1. Azt feltételezzük, hogy a vizsgált osztályokban a nem viszonzott rokonszenvi választásból kevesebbet találunk azonos nemü gyermekek között, mint a fiú - lány választásoknál. Vagyis a többséget képviselő nem tagjainak könnyebb - nagyobb esélyük van - kapcsolatok kialakítására, mint a kisebbségben lévőknek.

Jellemző ugyanis a két nem elkülönülése (gyermek)közösségekben is. Jelentős különbség mutatkozik a fiúk és a lányok társválasztásában, társas viselkedésében (Vajda, 2004). A saját 
nemü társ előnyben részesítése már korai életkorban (3 év) elkezdődik, és a kortárs csoportok egyre homogénebbekké válnak (N. Kollár, 2004). Serdülőkor előtt a gyerekek barát - és szimpátiaválasztásai szinte kizárólag az azonos nemü gyerekekre vonatkoznak. A nemek szerinti elkülönülés a fiúknál általában erősebb, mint a lányoknál - 8 éves fiúk 100\%-ban, a lányok 82\%-ban választanak azonos nemü társakat az iskolai szociometriában (DanielsBeioness, 1989, idézi Vajda, 2004). Edleson (1980) is azt találta, hogy az ugyanolyan nemü választások jelentősen magasabbak, mint az ellenkező nemü választások.

2. Feltételezzük, hogy a tanulók osztályban megszerzett pozíciója befolyásolja a viszonzott, illetve a nem viszonzott rokonszenvi választásokat. Úgy véljük, az azonos szociometriai státuszú társ felöl érkező választások általában viszonzásra találnak - függetlenül a közösség nemi arányaitól.

N. Kollár (2004) szintén említi, hogy a csoportban elfoglalt hely is befolyásolja a barát választását. Az iskolai osztályokban a hasonló pozícióban lévők, a hasonló presztizsüek gyakrabban választják egymást. Ez magyarázza azt, amikor az osztályokban egymásra találnak a perifériára szorult, népszerütlen tanulók vagy akár könnyebben válnak egy klikk tagjává (Kiss, Szekeres, 2016).

3. Végül a korábbi kutatási eredményeket alapul véve feltételezzük, hogy a lány többségü osztályokban rosszabb a lányok pozíciója - főleg ha enyhén értelmi fogyatékosok. Tehát jelen vizsgálat szerint a 4. osztályban lesz a legkedvezőtlenebb szociometriai helyzet, hiszen ott a lányok képviselik a többséget és az integrált tanuló is lány.

Fülöp (2004) arra hívja fel a figyelmet, hogy ha a fiúk és a lányok nem az ellentétes nemmel versengenek, hanem lányok a lányokkal és fiúk a fiúkkal, akkor a lányok sokkal kevésbé együttműködőek, mint a fiúk. Általában mind a fiúk, mind a lányok az azonos nemüeket tekintik természetes riválisnak, és csak másodsorban jelennek meg a másnemüek (Fülöp, 2004).

\section{Minta}

A vizsgálati mintát abból az országos mintavételből vettük, amelyet Szekeres Ágota (2011) gyüjtött és dolgozott fel doktori disszertációjában. Kutatásában olyan általános iskolák vettek részt, amelyekben 4., 5. és 6. osztályos enyhén értelmi fogyatékos gyermekek tanultak integrált körülmények között. Jelen vizsgálatban az országos mintavételben szereplö osztályok közül négynek a minőségi fókuszú elemzését végeztük el. A vizsgálati mintát alkotó 4 osztályban összesen 80 gyermek tanul: 42 fiú és 38 lány. Ebböl az integrált fogyatékos tanulók száma 4, 2 fiú és 2 lány. Az osztályok közül három 4. és egy 5. évfolyamú. A minta adatai az 1. táblázatban láthatók.

1. táblázat: A minta adatai (forrás: a Szerzők)

\begin{tabular}{|l|c|c|c|c|c|c|}
\hline Osztályok & Évfolyam & $\begin{array}{c}\text { Létszám } \\
\text { (fö) }\end{array}$ & $\begin{array}{c}\text { Fiú } \\
\text { (fó) }\end{array}$ & $\begin{array}{c}\text { Lány } \\
\text { (fö) }\end{array}$ & $\begin{array}{c}\text { Integrált } \\
\text { tanuló/fiú }\end{array}$ & $\begin{array}{c}\text { Integrált } \\
\text { tanuló/lány }\end{array}$ \\
\hline 1. osztály & 4. & 20 & 13 & 7 & 1 & 0 \\
\hline 2. osztály & 4. & 20 & 12 & 8 & 0 & 1 \\
\hline 3. osztály & 4. & 20 & 8 & 12 & 1 & 0 \\
\hline 4. osztály & 5. & 20 & 9 & 11 & 0 & 1 \\
\hline
\end{tabular}


A négy osztály azonos létszámú és mindegyikben 1-1 integrált gyermek tanul. Az 1. és 2. osztályban a fiúk vannak többen és az egyikben fiú, a másikban pedig lány az enyhén értelmi fogyatékos diák. A 3. és 4. közösségben lányok tanulnak többen, és az egyikbe 1 fogyatékos fiú, a másikba pedig 1 fogyatékos lány jár.

\section{Eszközök}

Vizsgálatunk módszeréül Mérei többszempontú szociometriáját választottuk, amely nemcsak az egyén helyét mutatja meg a társas mezőben, hanem magát a közösséget is jellemzi. Így pedagógiai és szervezési, tervezési támpontokat nyújthat az adott csoportban konfliktusok megelőzéséhez, a csoport közösségi erejének fejlesztéséhez (Mérei, 2001). A szociometriai felmérölapban 28, öt faktor mentén csoportosítható kérdés szerepelt: rokonszenvi választásokat feltételező, közösségi rátermettségre, versengésre, funkcióra vonatkozó, egyéni tulajdonságokra, képességekre, készségekre, adottságokra rákérdezö, beilleszkedési nehézségekre irányuló, és verbális agressziót feltérképező kérdések (Szekeres, 2012). Az adatok feldolgozása egy web alapú szoftverrel, a Smetry-vel történt (Szekeres Horváth, 2014).

\section{Eredmények}

\section{Az osztályközösségek mutatói}

A szociogramokat abból a szempontból vizsgáltuk, hogy mennyire strukturált az a társas mező, amelyet vázlatosan ábrázolnak. Ehhez a vizsgált alakzatok globális megítélése szükséges a szerkezeti mutatók segítségével.

A közösségek szerkezeti mutatóit, valamint a viszonyítás alapját képezö átlagértékeket az alábbi 2. táblázat foglalja össze.

\section{2. táblázat: Az osztályközösségek mutatói (forrás: a Szerzők)}

\begin{tabular}{|c|c|c|c|c|c|}
\hline Közösségek szerkezeti mutatói & $\begin{array}{c}1 . \\
\text { osztály }\end{array}$ & $\begin{array}{c}2 . \\
\text { osztály }\end{array}$ & $\begin{array}{c}3 . \\
\text { osztály }\end{array}$ & $\begin{array}{c}4 . \\
\text { osztály }\end{array}$ & $\begin{array}{l}\text { Mérei } \\
\text { (1971) }\end{array}$ \\
\hline \multicolumn{6}{|l|}{ Társas helyzetek } \\
\hline 1. magányosak & $10 \%$ & $15 \%$ & $15 \%$ & $10 \%$ & $12 \%$ \\
\hline 2. páros helyzetüek & - & - & - & $20 \%$ & $8 \%$ \\
\hline 3. lánchelyzet & $50 \%$ & $25 \%$ & $30 \%$ & $55 \%$ & $15 \%$ \\
\hline 4. csillaghelyzet & - & - & - & - & $19 \%$ \\
\hline 5. zárt alakzatok & & & & & \\
\hline a. háromszög & - & $15 \%$ & $15 \%$ & $15 \%$ & $12 \%$ \\
\hline $\begin{array}{l}\text { b. négyszög és nagyobb } \\
\text { alakzatok }\end{array}$ & $40 \%$ & $45 \%$ & $40 \%$ & - & $34 \%$ \\
\hline \multicolumn{6}{|l|}{ Kohéziós mutatók } \\
\hline 1. kölcsönösségi index & $90 \%$ & $85 \%$ & $85 \%$ & $90 \%$ & $85-90 \%$ \\
\hline 2. sürüségi mutató & 0,95 & 1,1 & 1,1 & 0,7 & $0,9-1,1$ \\
\hline 3. kohéziós index & $10 \%$ & $12 \%$ & $12 \%$ & $7 \%$ & $10-13 \%$ \\
\hline 4. viszonzottsági mutató & $51 \%$ & $47 \%$ & $40 \%$ & $42 \%$ & $40-50 \%$ \\
\hline
\end{tabular}


Társas helyzetek

A társas mező struktúráját a zárt alakzatok - háromszög, négyszög és nagyobb alakzat-, a csillagok elrendezése, a láncok hosszúsága a páros helyzetűek és a magányosok száma is jellemzi.

Az általunk vizsgált négy közösség közül háromban a zárt alakzatok dominanciája figyelhető meg (50\%), melyek aránya meghaladja a Mérei-féle átlagértéket (46\%). A 4. osztályban azonban csak háromszögben helyet foglaló tanulókat találunk, nagyobb zárt társas helyzet nem fordul elő. A zárt alakzatok aránya a szervezettségnek, a közvélemény - alakító képességnek a fokméröje (Mérei, 2001). A zárt alakzatokhoz lánc is kapcsolódik, amely a vélemények továbbítását, a közvéleményt, illetve egy kisebb egység álláspontjának a kialakulását segíti elő. Érdekes, hogy mindegyik osztályban sokkal többen foglalnak helyet láncban, mint Mérei mintájában. A központ(ok)ból elágazó csillagok szerepe a szétágazó hírés véleményközlés biztosítása lenne, de csillagot nem találunk a szociogramokon, a Méreiféle 19\%-tól igen elmaradva. A páros kapcsolatok is hiányoznak három közösségböl. Mindössze a 4. osztályban találunk párban álló tanulókat - viszont ök többen vannak így elszigetelődve (20\%), mint az a közösség egészséges légkörét (8\%) biztosítaná. A magányosok száma mindegyik osztályban átlagosnak mondható.

Összegezve a négy osztály struktúrájáról kapott értékeket, elmondható, hogy az „ismert” társas helyzetek és azok átlagos előfordulási gyakorisága nem releváns ezekre a közösségekre. Teljesen hiányoznak a csillaghelyzetben lévő - és egy osztály kivételével - a párban álló tanulók. Láncban azonban lényegesen többen vannak (40\%), mint a Mérei által rögzített 15\%.

$\mathrm{Az}$ imént részletezett társas helyzetekben helyet foglaló tanulók arányát osztályonkénti és nemek szerinti bontásban a következő ábrák mutatják be. (1., 2., 3., 4. ábra)

A több fiút - és köztük fiú integrált tanulót - számláló osztályban a fiúk 16\%-a magányos, 54\%-uk láncban és 30\%-uk zárt, szorosabb kapcsolatban helyezkedik el. A lányok csak két helyzetben fordulnak elö: láncban, illetve nagyrészük négyszögben, vagy nagyobb zárt alakzatban (1. ábra).

1. ábra: A különbözö társas helyzetekben helyet foglaló tanulók aránya (\%) az 1. osztályban (forrás: a Szerzők)

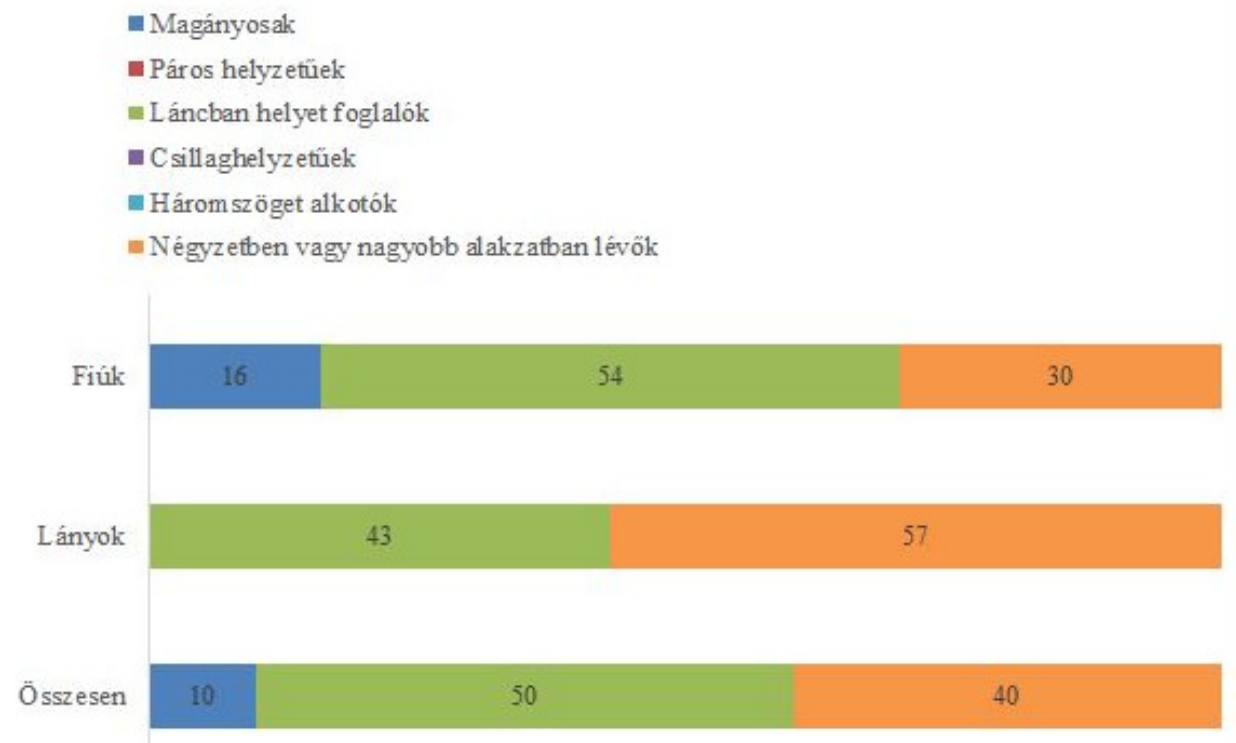


Az 1. és 2. osztály azonos létszámú, és mindkettőben több fiú tanul. Annyi különbséget tudunk még róluk, hogy az egyikben fiú, a másikban lány az integrált diák. Az osztályok struktúrája azonban több eltérést mutat. Az 1-ben a fiúk három (magányos, lánc, nagyobb zárt), a lányok csak kétféle pozícióban (lánc, nagyobb zárt alakzat) vannak. Ez nem jelent túl nagy differenciálódást, inkább csak két lehetőség közötti választást: vagy ide tartozik valaki, vagy oda, vagy magányos marad. A 2. osztályban eggyel bővül mindkét nem pozíciós lehetősége, és az arányok is változnak. A fiúk 75\%-a zárt alakzatokban (háromszögben és nagyobb zárt helyzetben) van, a lányoknak pedig csak kicsit több, mint egyharmada (37,5\%) tart szoros kapcsolatot társaival (2. ábra).

2. ábra: A különbözö társas helyzetekben helyet foglaló tanulók aránya (\%) a 2. osztályban (forrás: a Szerzők)

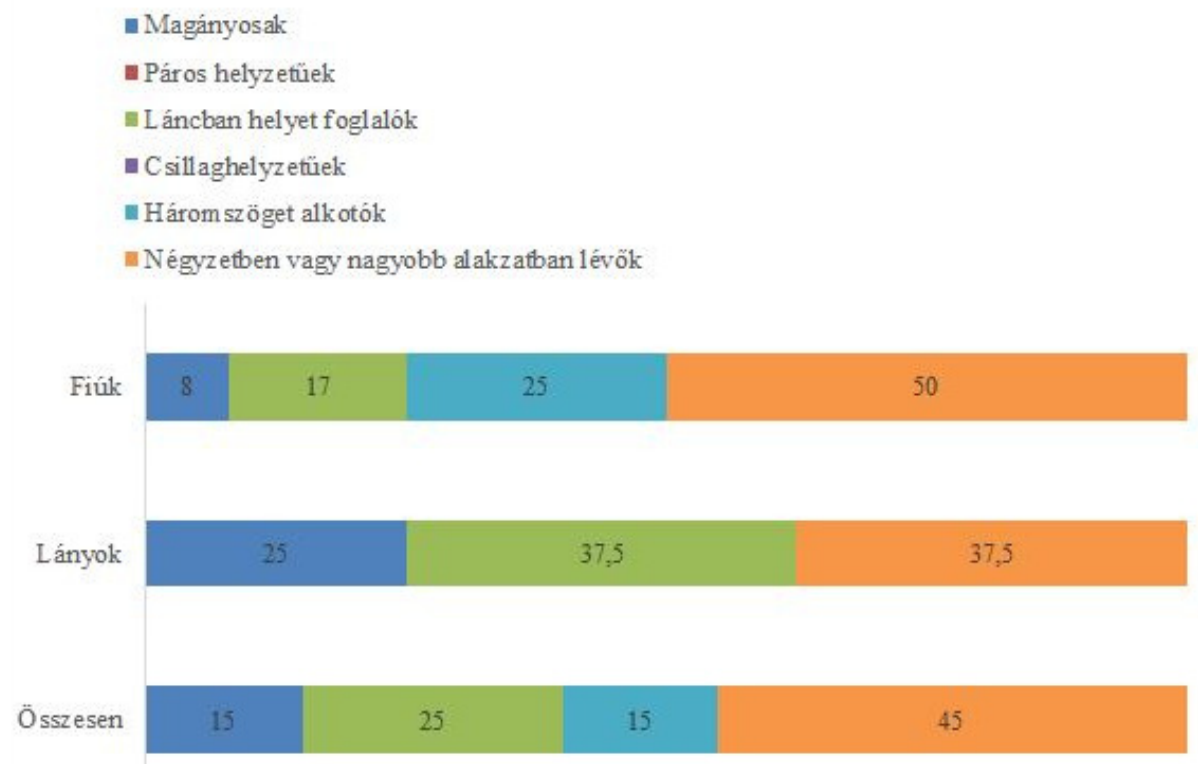

Legnagyobb eltérés a két nem között - a társas helyzetekben való előfordulás arányát tekintve - a 3. és a 4. osztályban figyelhető meg. Ezen osztályokban több a lány, az egyikben fiú, a másikban pedig lány a fogyatékos tanuló.

A fiút integráló 3. osztályban (3. ábra) a magányosak és a négyszögben, vagy nagyobb zárt alakzatban lévők mind a lányok közül kerülnek ki, és a lánchelyzetü lányok is lényegesen kevesebben vannak, mint a lánchelyzetü fiúk. A lányok kétharmada erős magot képez, és nem nagyon engedik magukhoz lánytársaikat sem - csupán kis lánc tartozhat hozzájuk, a többiek pedig egyedül maradtak.

A fiúk arányai megfordulnak a lányokéihoz képest: majd kétharmaduk van láncban, a többiek pedig háromszögben zárnak össze. Másféle pozíció nincs náluk ebben a közösségben. Ez hasonló a korábban részletezett 1. osztály kevés pozícionális alternatívát tartalmazó lánycsapatához. Tehát: az 1. osztályban több fiú van, és a lányok vannak két pozícióba „rendezve”, a 3. osztályban több lány van, és a fiúk társas helyzete csupán kétféle. Olyan, mintha az ellenkező nemü többség a másik nem társas mobilitását korlátozná. 
3. ábra: A különbözö társas helyzetekben helyet foglaló tanulók aránya (\%) a 3. osztályban (forrás: a Szerzők)

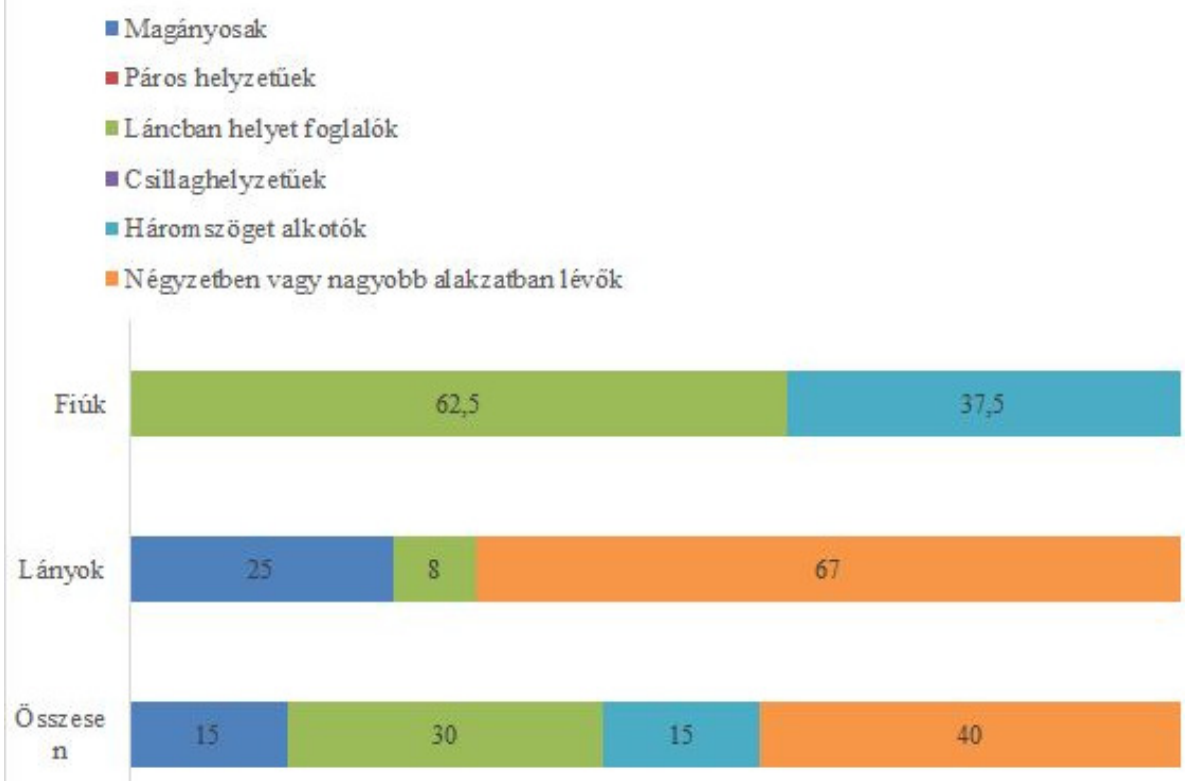

A 4. - sajátos nevelési igényü lányt integráló közösség (4. ábra) - nemek szerinti legnagyobb eltérése a láncban álló lány-dominanciában és a csak fiúkat érintő zárt helyzetekben mutatkozik meg. A magányos és a láncban lévő fiú - lány arány eltérése nem jelentős. A lányok kapcsolataiban szokatlan módon nincs 2-3 fös „összezárás”, intim barátnői együttlétekre utaló csoportosulás.

4. ábra: A különbözö társas helyzetekben helyet foglaló tanulók aránya (\%) a 4. osztályban (forrás: a Szerzők)

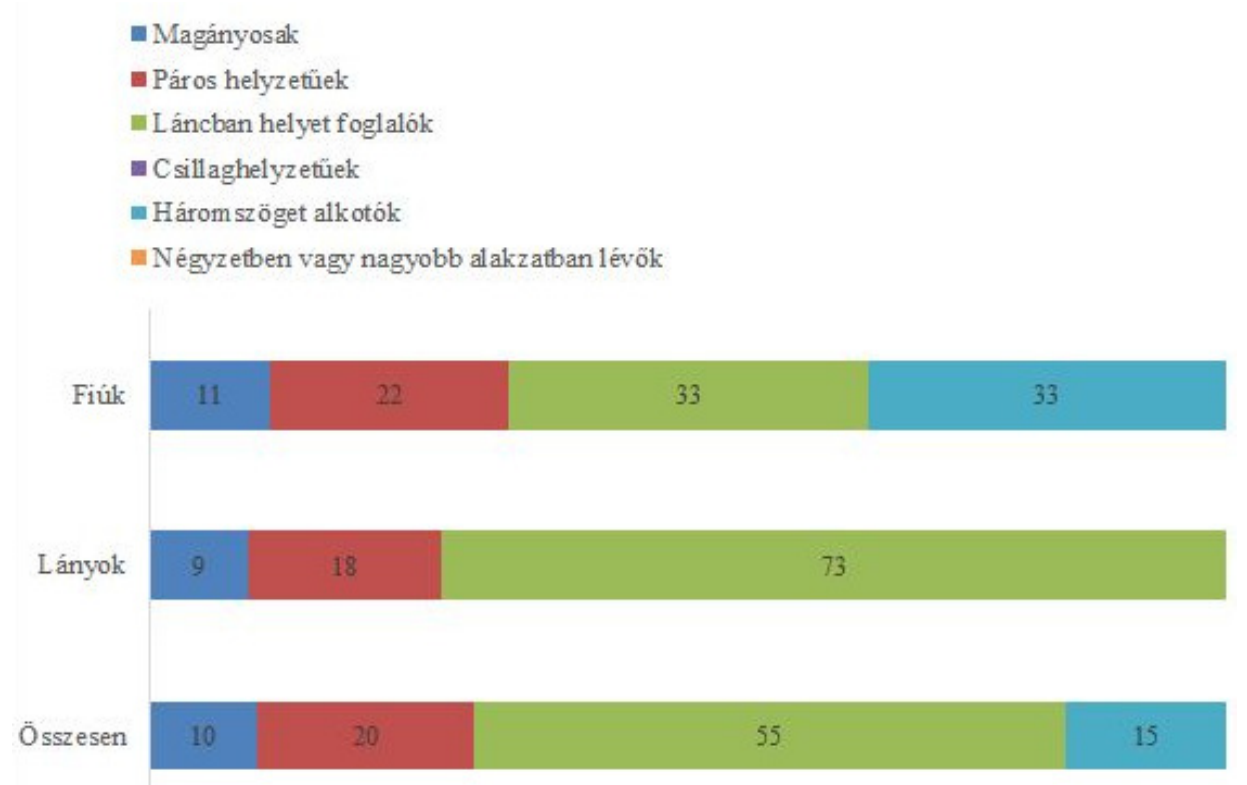


Ez a közösség különbözik leginkább a másik háromtól struktúrájában, vagy éppen struktúrálatlanságában. Nincs benne egyik nem tagjaiból álló négyszöget vagy nagyobb zárt alakzatot alkotó diákcsoport sem, viszont páros elszigetelődésben állók előfordulnak a fiúk és lányok között is. Közösségi élet, közös élmények, közös tevékenységek, célok nehezen képzelhetőek el ebben az osztályban.

\section{Az osztályok szociogramjai}

$\mathrm{Az}$ osztályok szociogramjai (5. ábra) láthatóvá teszik az eddig számokban kifejezett értékeket, és a közösségek közötti különbségeket.

5. ábra: szocigramok (forrás: a Szerzök).

1. osztály:
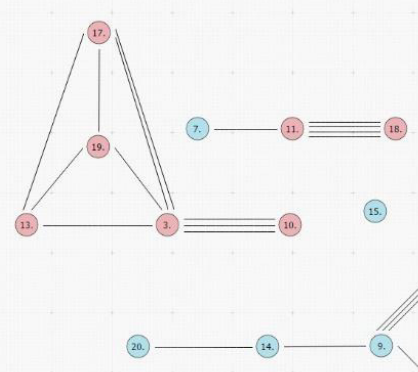

(20.)

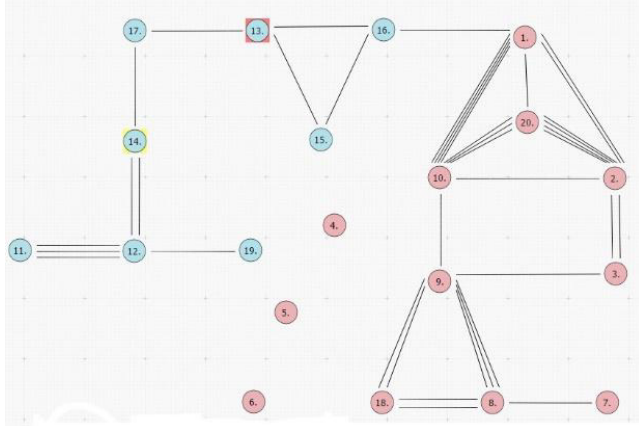

2. osztály:

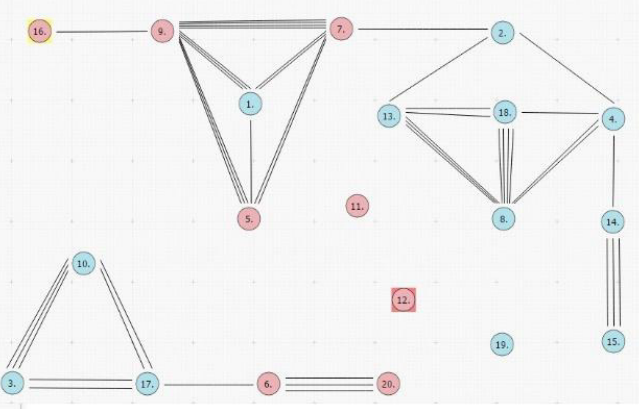

4. osztály:

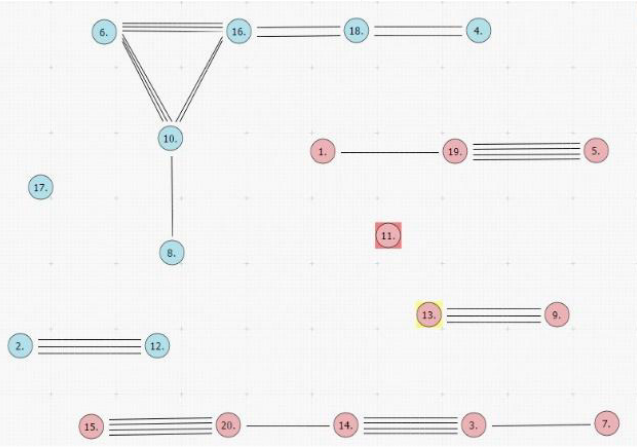

Az 1. közösség (5. ábra) fiú és lány csoportban különül el, mindössze egy fiú kötődik egy lányokból álló lánchoz. A lányoknál lévő szoros mag négy föt számlál, melyhez egy társuk láncban kapcsolódik. Még egy fiúból és két lányból álló lánc is szerepel a szociogramon a két magányos fiú - az egyik integrált -, és a fiúk többségét magában foglaló csoport mellett. A fiúk társas helyzetére négy főből álló zárt alakzat és ehhez kapcsolódó három lánc tartozik.

A 2. osztály (5. ábra) egy nagyobb és egy kisebb csoportra szakadt, és három magányos tanuló - két lány és egy fiú - is van a közösségben. A nagyobb csoportot fiúk és lányok együtt alkotják; és a lányok szoros közösségében egy fiú is helyet kapott, míg a hozzájuk kapcsolódó fiú-társaság nemi szempontból homogén. A kisebb csoport egy fiúk alkotta háromszögböl, és ehhez kapcsolódó két lányból áll. A vizsgálatban szereplő 3. osztály három magányos lány kivételével egy nagy csoportot alkot. A fiúk és lányok közössége „egy ponton" kapcsolódik össze. 
A 4. osztály (5. ábra) közösségnek alig nevezhető. A két magányos tanuló (egy fiú, egy lány) mellett négy páros elszigetelődésben lévő tanuló (két fiú, két lány), és két lányokból álló lánc látható a szociogramon. Mindössze a hat fiú alkotta háromszög és a hozzá kapcsolódó lánc mutat valamiféle struktúrát. A lányok egymástól külön-külön láncokban „müködnek”, csupán a néhányuk között lévő erősebb kötődés biztosítja a láncszerü kapcsolatot is.

\section{Rokonszenvi választások alakulása az osztályokban}

Az osztályközösségek kölcsönösségi táblázata tartalmazza a - szociogram felrajzolásához is szükséges - rokonszenvi választásokat. Ezek közül a deklarált kapcsolatokból kölcsönössé válókat, azaz a viszonzott kapcsolatokat elemeztük - nemek szerint. A négy osztály összesített adatait a 3. táblázat tartalmazza.

Az 1. osztályban a fiúknak kétszer annyi választásuk volt (50), mint a lányoknak (25), de csak néggyel több talált viszonzásra a lányok viszonzott kapcsolataihoz képest.

A 2. közösségben szintén a fiúk deklarált kapcsolata a több (56), mint a lányoké (37), de itt több is lesz viszonzott a fiúknak (29), és kevesebb a lányoknak (15) belöle.

A 3. lány-többségü osztályban a lányok kölcsönös kapcsolatainak aránya kedvezőbb, mint a fiúké. Az összesítésnél azonban a nem kölcsönös kapcsolatok felé történő eltolódás látható a közösségben.

Végül a szintén lány-fölényü közösségben - ahol az integrált tanuló is lány - arányaiban kevesebb kölcsönös kapcsolat jut a lányokra, mint a kevesebb föt számláló fiúkra. A 4. osztálynál is a kölcsönössé nem váló kapcsolatok dominálnak.

3. táblázat: Választások alakulása az osztályokban (forrás: a Szerzők)

\begin{tabular}{|l|c|c|c|c|c|c|c|c|}
\hline \multirow{2}{*}{\multicolumn{1}{|c}{ Kapcsolatok }} & \multicolumn{2}{|c|}{ 1. osztály } & \multicolumn{2}{c|}{ 2. osztály } & \multicolumn{2}{c|}{ 3. osztály } & \multicolumn{2}{c|}{ 4. osztály } \\
\cline { 2 - 11 } & Fiúk & Lányok & Fiúk & Lányok & Fiúk & Lányok & Fiúk & Lányok \\
\hline Deklarált kapcsolatok & 50 & 25 & 56 & 37 & 50 & 59 & 30 & 37 \\
\hline Kölcsönös kapcsolatok & 21 & 17 & 29 & 15 & 17 & 27 & 14 & 14 \\
\hline $\begin{array}{l}\text { Nem kölcsönös } \\
\text { kapcsolatok }\end{array}$ & 29 & 8 & 27 & 22 & 33 & 32 & 16 & 23 \\
\hline
\end{tabular}

Nem viszonzott rokonszenvi választások

Kíváncsiak voltunk, hogy a tanulók közötti kapcsolatok alakulásában mekkora szerepet játszottak a nem viszonzott rokonszenvi választások. Ezek lehetnek a tanulók által leadott és társaik által nem viszonzott, illetve a tanulók felé irányuló, de általuk nem viszonzott választások is. Az adatok rögzítését nemcsak nemek szerint differenciáltuk, hanem jelöltük a választások irányát is: milyen társas helyzetben lévő társ felé irányul, illetve milyen pozíciójú társ felől érkezik. Az osztályok eredményeit a 4. és 5. táblázatok tartalmazzák.

A fiúk mind a négy osztályban küldenek választást mindkét nem felé, de választásainak 71\%-át fiúk, 29\%-át lányok nem viszonozzák (4. táblázat). Társaik legyenek bármilyen pozícióban, potenciális jelöltek lehetnek barátság számára. Azt állapította meg Vajda (2004) is, hogy a fiúk gyakrabban reagálnak pozitívan egy új baráti felajánlkozásra, mint a lányok. A fiúcsoportokban azonban általában több viszonzatlan választás irányul az alacsonyabb státuszúaktól a magasabb státuszúak felé (Vajda, 2004). Ebben az osztályban különösen a 
láncban, zárt alakzatban, központban lévő fiúk barátsága vonzó a többi fiúnak. Az integrált fiú tanulók 57\% -ban szintén fiúhoz és 43\%-ban lányhoz irányítják rokonszenvi választásukat, tehát ök úgy „müködnek”, mint többségi társaik.

4. táblázat: A tanulók által leadott rokonszenvi választások (forrás: a Szerzők)

\begin{tabular}{|c|c|c|c|c|c|c|c|c|c|c|c|c|c|}
\hline & \multirow{2}{*}{\multicolumn{2}{|c|}{$\begin{array}{c}\text { Magányos } \\
\text { Fiúfelé Lány felé }\end{array}$}} & \multicolumn{2}{|c|}{ Párbana álló } & \multicolumn{2}{|c|}{ Láncban lévo" } & \multicolumn{2}{|c|}{ Zárt alakzatban lévo" } & \multicolumn{2}{|c|}{ Központban lérö } & \multicolumn{2}{|c|}{$\begin{array}{c}\text { Összes kimenono } \\
\text { válastás }\end{array}$} & \multirow{2}{*}{ Összesen } \\
\hline & & & Filífelé & Lány felé & Fílífelé & Lány felé & Fiú felé & Lány felé & Fiú felé & Lány felé & & Lány felé & \\
\hline Finu(40) & 4 & 3 & 3 & 0 & 32 & 11 & 35 & 0 & 22 & 25 & 96 & 39 & 135 \\
\hline Lány (36) & 3 & 5 & 1 & 0 & 7 & 23 & 5 & 9 & 4 & 43 & 20 & 80 & 100 \\
\hline Int. 2 fiú & 0 & 0 & 0 & 0 & 2 & 0 & 2 & 0 & 0 & 3 & 4 & 3 & 7 \\
\hline Int. 2 lány & 0 & 1 & 0 & 2 & 1 & 4 & 0 & 0 & 1 & 3 & 2 & 10 & 12 \\
\hline
\end{tabular}

A lányok kisebb arányban nyitnának fiúk felé és inkább a lányokkal szeretnének kapcsolatot létesíteni. Különösen a láncban, zárt társas helyzetben, központban lévőkkel barátkoznának, de a magányosokat sem hagynák egyedül, ha visszaválasztanák őket. A lányok kimenő választásainak $80 \%$-át a saját nemük, és $20 \%$-át az ellenkező nemü fiúk utasítják vissza. Az integrált lányok osztálytársaik felé irányuló választásait 10\%-ban nem fogadják a fiúk, és 90\%-ban a többségi lányok (4. táblázat).

A fiúk felé arányaiban kevesebb olyan választás irányul a vizsgált közösségekben, amit ök nem viszonoznak (5. táblázat). Vagyis több választást indítanak (lásd előző táblázat), mint a lányok és így több is célba ér, viszonzásra talál. A fiúk bátrabban próbálkoznak és jól is teszik, mert így több esélyük van kapcsolatok kialakítására. A fiú tanulók felé irányuló és általuk nem viszonzott rokonszenvi választások $85 \%$-ban a saját nemük felöl, és $15 \%$-ban lányok felől jönnek.

5. táblázat: A tanulók felé irányuló rokonszenvi választások (forrás: a Szerzők)

\begin{tabular}{|c|c|c|c|c|c|c|c|c|c|c|c|c|c|}
\hline & $\begin{array}{r}\text { Ma } \\
\text { Fíu felolol }\end{array}$ & $\begin{array}{l}\text { ányos } \\
\text { Lány felolil }\end{array}$ & $\begin{array}{r}\text { Pár } \\
\text { Fiú felöl }\end{array}$ & $\begin{array}{l}\text { and álló } \\
\text { Lány felöl }\end{array}$ & $\begin{array}{l}\text { Lán } \\
\text { Fiú felö }\end{array}$ & $\begin{array}{l}\text { ban lévo" } \\
\text { Lány felöl }\end{array}$ & $\begin{array}{l}\text { Zárt ala } \\
\text { Fír felolol }\end{array}$ & $\begin{array}{c}\text { zatban lév" } \\
\text { Lány felöl }\end{array}$ & $\begin{array}{r}\text { Közpp } \\
\text { Fíu felöl }\end{array}$ & $\begin{array}{l}\text { ban lévo" } \\
\text { Lány felolil }\end{array}$ & $\begin{array}{r}\text { ÖsSZ } \\
V \\
\text { Fiú felo }\end{array}$ & $\begin{array}{l}\text { sbejörö } \\
\text { astáás } \\
\text { Lány felöl }\end{array}$ & Összesen \\
\hline Fini (40) & 13 & 3 & 3 & 2 & 45 & 10 & 21 & 0 & 15 & 2 & 97 & 17 & 114 \\
\hline Lány (36) & 1 & 29 & 0 & 5 & 16 & 29 & 16 & 6 & 5 & 21 & 38 & 90 & 128 \\
\hline Int. 2 fiú & 0 & 0 & 0 & 0 & 2 & 0 & 1 & 0 & 0 & 0 & 3 & 0 & 3 \\
\hline Int. 2 lanny & 0 & 0 & 0 & 0 & 1 & 0 & 0 & 0 & 0 & 0 & 1 & 0 & 1 \\
\hline
\end{tabular}

A lányok több feléjük nyújtott kezet utasítanak el, ök óvatosabbak a fiúknál. Viszont a fiúk felöl jövő szándékokat nagyobb arányban nem erősítik meg (30\%), mint azt a fiúk a lányok felől érkezőkkel tették (15\%). Továbbá a lányok a szintén lányok felől érkező választások 70\%-át, a fiúk felől érkezők 30\%-át utasítják vissza. Integrált lány felé mindössze egy fiú felöl érkező visszautasított választást találtunk. (5. táblázat)

A tanulók által leadott és társaik által ezeket nem viszonzott kapcsolatokat nézve (4. táblázat) a fiúknak van több (135 db többségieknek $+7 \mathrm{db}$ integráltaknak) és a lányoknak kevesebb (100 db többségieknek +12 db integráltaknak). A feléjük jövő és általuk nem 
viszonzott választásokból (5. táblázat) pedig a fiúknak van kevesebb $(114 \mathrm{db}+3 \mathrm{db})$ és a lányoknak több $(128 \mathrm{db}+1 \mathrm{db})$. Az összes nem viszonzott rokonszenvi választásból így a lányokra $241 \mathrm{db}$, tehát $6,3 \mathrm{db} /$ fö esik. A fiúkra pedig az összes $259 \mathrm{db}$ nem viszonzott rokonszenvi választásból 6,2 jut egy före. Tehát szinte nincs különbség a fiúk és lányok összesített eredményei között.

A nem viszonzott rokonszenvi választások vizsgálatának eredménye alapján elmondható, hogy a fiúk többféle pozícióban lévő társuk felé intéznek több rokonszenvi választást, mint azt a lányok saját nemük körében teszik. Nyitottabbak, bátrabban kezdeményeznek, kockáztatnak esetleg visszautasítást is. A lányok kevesebb választást indítanak az ellenkező nem felé, mint a fiúk tették feléjük. Ök kevésbé bízzák az esetlegességre barátságaikat, biztosra akarnak menni, mégis kevésbé tudnak beilleszkedni az osztályukban. Ha azonban erős néhányuk között a kapcsolat, nehezen engednek be másokat.

$\mathrm{Az}$ is elöfordul mindkét nem képviselőinél, hogy a választások félremennek, és a tanulók nem ismerik fel a potenciális kapcsolat lehetőségét (Szekeres és Horváth, 2014).

\section{Hipotézisek beválásának vizsgálata}

A vizsgálat elején megfogalmazott három hipotézis közül kettő jól látható eredményekben realizálódott, egy pedig nem nyert igazolást:

1. Azt gondoltuk, hogy a vizsgált osztályokban a nem viszonzott rokonszenvi választásból kevesebbet találunk azonos nemü gyermekek között, mint a fiú - lány választásoknál. A hipotézis felállításánál N. Kollár (2004) megállapítására is támaszkodtunk, miszerint a barátság és a párkapcsolat is döntően a hasonlóságokra épül. Kiegyensúlyozott kapcsolatok sokkal gyakrabban szövődnek a hasonlóság, mint a különbözőség alapján. Az azonos nemhez tartozást olyan hasonlóságnak véltük, amely kevesebb visszautasítást indokol fiúk-fiúk, és lányok-lányok választásaiban.

Feltételezésünket nem erősítették meg a kapott eredmények. Mind a négy osztályban ellenkező adatok születtek. A tanulók által leadott és társaik által nem viszonzott kapcsolatokat nézve a fiúknak van több és a lányoknak kevesebb, de a feléjük jövő és általuk nem viszonzott választásoknál megfordul az arányuk: a fiúknak van kevesebb és a lányoknak több. A részeredmények összesítéséből azonban kiderült, hogy szinte nincs különbség a fiúk és lányok saját nemükön belül történő visszautasított választásaik terén.

2. Feltételeztük, hogy a tanulók osztályban megszerzett pozíciója befolyásolja a viszonzott, illetve a nem viszonzott rokonszenvi választásokat. Úgy véltük, az azonos szociometriai státuszú társ felöl érkező választások általában viszonzásra találnak - függetlenül a közösség nemi arányaitól. Korábbi kutatási eredményekből tudjuk (N. Kollár, 2004, F. Lassú, 2004), hogy a csoportban elfoglalt hely is befolyásolja a barát választását. Az iskolai osztályokban a hasonló pozícióban lévők, a hasonló presztizsủek gyakrabban választják egymást.

Mindkét nem esetében valóban azok a rokonszenvi választások kerültek nagyobb arányban viszonzásra, melyet a társ azonos, vagy hasonló, „közeli” társas helyzetből kezdeményezett. Eltérés a fiúk és lányok között abban van, hogy a fiúk legyenek bármilyen pozícióban, nagyobb számban tartják egymást potenciális jelöltnek barátság számára, mint a lányok maguk között teszik. A fiúk tehát bátrabban kezdeményeznek kapcsolatot, hajlandóak nyitni más szociometriai státuszú diákok felé - fölfelé és lefelé - is, vállalva a kialakuló hierarchiát, vagy akár az esetleges elutasítás lehetőségét. A lányok érdeklődése jellemzően az azonos pozíciójúak felé irányul. Ök kevésbé mernek kockáztatni választásaikban, sőt néha annyira óvják köreiket, hogy még az azonos helyzetből csatlakozni kívánó lánytársaikat sem engedik magukhoz közel. Az integrált tanulók választásai a többségi társaik attitüdjét tükrözi. 
3. Végül a korábbi kutatási eredményeket alapul véve azt gondoltuk, hogy a lány többségü osztályokban rosszabb a lányok pozíciója - főleg ha enyhén értelmi fogyatékosok. Tehát jelen vizsgálat szerint a 4. osztályban lesz a legkedvezötlenebb szociometriai helyzet, hiszen ott a lányok képviselik a többséget és az integrált tanuló is lány.

Ez beigazolódott, mert ebben a közösségben hiába van több lány, csak láncokban, illetve párban kapcsolódnak egymáshoz, és semmilyen szorosabb összetartozást tükröző zárt társas helyzetet nem alkotnak. A magányos integrált lánynak pedig egyikőjük rokonszenvét sem sikerült elnyernie.

\section{Összegzés}

A szocializációs megközelítés a nemi különbségek hátterében a két nemmel szemben felállított eltérő szabályokat, elvárásokat és bánásmódot emeli ki (Sherrod, 1989 idézi F. Lassú, 2004). Hátterében a szülők eltérő bánásmódja áll. Apák a fiúknál bátorítják a teljesítményt, a függetlenséget és a kompetenciát, és büntetik a függőséget, az érzelmek és a kötődés kimutatását. A fiúk kiskorukban erősebb és változatosabb ingereknek vannak kitéve, később nagyobb szabadságot kapnak, kevesebbet aggódnak értük és figyelnek rájuk, viszont magasabbak velük szemben az elvárások. A lányok mindkét szülőjüktől elfogadóbb reagálást kapnak. A lányokkal csecsemőként finomabban bánnak, jobban aggódnak értük, és többet figyelnek rájuk, sokkal több korlátozást élnek meg. A lányok ebből adódóan kapcsolatokba ágyazottak, gondoskodók, viszonyaikra a kölcsönös törődés a jellemző; a fiúk ezzel szemben instrumentálisak, versengők és elkülönültek - kapcsolataikban a kölcsönös tevékenység a hangsúlyos (Anh L. L., 2004). Ez megnyilvánul iskolai közösségi életük során is, és megmutatkozik társ/barátválasztási attitüdjükben.

Nehezíti a lányok iskolai pályafutását, hogy önértékelésükben az iskola szerepe, az iskolai teljesítmény, a kognitív képességek szerepe nagy. A fogyatékos lányok esetében a tanulmányi teljesítmény ugyanolyan kiemelt szereppel bír, mint a többségi tanulóknál, csak ök ennek az elvárásnak nem tudnak megfelelni, ezért önértékelésük és iskolai beilleszkedésük is problémás. A fiúknál az iskola csak egy az önismeretet formáló visszajelzések közül a sport és a szakkörök mellett (Körössy, 2004). Ebben az életkorban a fiúk közösségét sokkal inkább a nem kognitív tevékenységek tartják össze - ezzel magyarázható, hogy a fiúk miért összetartóbbak nagyobb csoportokban. Lányoknál inkább a kisebb létszámú közösségekben erős a kohézió.

Az integrált tanulók általában a saját nemükhöz akarnak tartozni, hogy milyen pozíciójú társhoz - fölfelé vagy lefelé - akarnak-e kapcsolódni, az inkább személyiségfüggő. Integrált gyermek befogadásánál erösebb a fiúközösség vezetőjének/vezérének a véleménye, mint a lányoknál. Ha több a fiú, nagyobb a mag - erősebb a „vezér” szerepe. Ha a fogyatékos gyermeknek sikerül őt meggyőznie, akkor sikerülni fog a csapat tagjává válnia. A szociometriai státusz nem egyes személyiségjellemzőknek köszönhető, hanem tulajdonságcsoportoknak, illetve tulajdonságok interakciójának (N. Kollár, 2004).

A Mérei-féle szociometria elvei, rendszere, szerkezete, megközelítési módjai természetesen időtállóak a jelenben is. Az viszont elgondolkodtató, hogy az egyes paraméterek, illetve az akkori numerikus értékek több, mint 40 éves „koruk” miatt relevánsak - e még. A kutatás adatai viszonyítási alapul szolgálnak, de nem teszik lehetővé a statisztikai elemzés útján történő összehasonlítást (Szekeres és Horváth, 2014). Érdemes lenne az SNI populációt integráló közösségek - óvodai csoportok, iskolai osztályok, munkahelyi közösségek körében végzett szociometriai felmérés alapján új, speciálisan „erre a népességre” standard értékeket felállítani.

Köszönetnyilvánítás: a publikáció megírását a MTA Bolyai János Kutatói Ösztöndíj támogatta. 


\section{Irodalom:}

Bakker, J. T. A., Denessen, E., Bosman, A. M. T., Krijger, E., \& Bouts, L. (2007). Sociometric status and self-image of children with specific and general learning disabilities in Dutch general and special education classes. Learning Disability Quarterly, 30 (Winter), 47-62.

Baydik, B., \& Bakkaloglu, H. (2009). Predictors of sociometric status for low socioeconomic status elementary mainstreamed students with and without special needs. Educational Sciences: Theory\&Practice, 9 (2), 435-445.

Edleson, J. L. (1980). The effect of sex differences on sociometric data generated by a rosterrating scale instrument. Journal of Behavioral Assessment, 2 (4), 249-254.

Fiasse, C., \& Nader-Grosbois, N. (2012). Perceived social acceptance, theory of mind and social adjustment in children with intellectual disabilities. Research in Developmental Disabilities, 33 (6), 1871-1880.

F. Lassú, Zs. (2004). A nemek kérdése - szexualitás az iskolában In N. Kollár, K. \& Szabó, É. (szerk.), Pszichológia pedagógusoknak (pp. 551-562) Budapest: Osiris Kiadó.

F. Lassú, Zs. (2015). „Természetesen a fiúk hülyék voltak” - kisiskoláskori baráti kapcsolatok fiatal felnőtt nők visszaemlékezéseinek tükrében. Gyermeknevelés, 3 (1), 1-17.

Fülöp, M. (2004). Versengés az iskolában. In Mészáros, A. (szerk.), Az iskola szociálpszichológiai jelenségvilága (pp. 221-244) Budapest: ELTE Eötvös Kiadó.

Gilmore, L., \& Cuskelly, M. (2014). Vulnerability to loneliness in people with intellectual disability: An explanatory model. Journal of Policy and Practice in Intellectual Disabilities, 11 (3) 192-199.

Grüning, E. (2012). Forschungsbericht: Inklusive Bedingungen an Allgemeinen Schulen für Kinder und Jugendliche mit geistigen Behinderungen. Zeitschrift für Heilpädagogik, 6 250-258.

Herbainé Szekeres, E. \& Szekeres, Á. (2016). Enyhén értelmi fogyatékos gyermekeket integráló "jó" és "rossz" közösségek összehasonlítása. Gyógypedagógiai Szemle, XLIV, 149-167.

Körössy, J. (2004). Az énkép és összefüggése az iskolai teljesítménnyel. In Mészáros, A. (szerk.), Az iskola szociálpszichológiai jelenségvilága (pp. 83-101) Budapest: ELTE Eötvös Kiadó.

Kovács, M. (2014). Nemi sztereotípiák és elöítéletek az iskolában. In Gordon Győri, J. (szerk.), Tanárok interkulturális nézetei és azok hatása az osztálytermi munkára. A multikulturális és interkulturális szemlélet elméleti alapjai és történeti vonatkozásai az oktatásban (pp. 45-51) Budapest: ELTE Eötvös Kiadó.

Kucukera, S., \& Tekinarslanb, I. C. (2015). Comparison of the Self-Concepts, Social Skills, Problem Behaviors, and Loneliness Levels of Students with Special Needs in Inclusive Classrooms. Educational Sciences: Theory \& Practice, 6, 1559-1573.

Luu Lan Anh, N. (2004). A nemek szerepe az iskolában. In Mészáros, A. (szerk.), Az iskola szociálpszichológiai jelenségvilága (pp. 117-130) Budapest: ELTE Eötvös Kiadó.

Mand, J. (2007). Social position of special needs pupils in the classroom: a comparison between German special schools for pupils with learning difficulties and integrated primary classes. European Journal of Special Needs Education, 22 (1), 7-14.

Mérei, F. (2001). Közösségek rejtett hálózata. Budapest: Osiris Kiadó.

Mesterházi, Zs. (1998). A nehezen tanuló gyermekek iskolai nevelése. Budapest: Bárczi Gusztáv Gyógypedagógiai Tanárképző Főiskola.

van Nieuwenhuijzen, M., Orobio de Castro, B., Wijnroks, L., Vermeer, A., \& Matthys, W. (2004). The relations between intellectual disabilities, social information processing, and behaviour problems. European Journal of Developmental Psychology, 1 (3), 215-229. 
N. Kollár, K. (2004). A társas kapcsolatok, személyközi vonzalom és a csoportfolyamatok In N. Kollár, K. \& Szabó, É. (szerk.), Pszichológia pedagógusoknak (pp. 280-309) Budapest: Osiris Kiadó.

Papoutsaki, K., Gena, A., \& Kalyva, E. (2013). How do children with mild intellectual disabilities perceive loneliness? Europe's Journal of Psychology, 9 (1), 51-61.

Piercy, M., Wilton, K., \& Townsend, M. (2002). Promoting the social acceptance of young children with moderate-severe intellectual disabilities using cooperative-learning techniques. American Journal on Mental Retardation, 107 (5), 352-360.

Pijl, S. J., \& Frostad, P. (2010). Peer acceptance and self $\square$ concept of students with disabilities in regular education. European Journal of Special Needs Education, 25 (1), 93-105.

Schneider, B. H. (2016). Childhood Friendships and Peer Relations. Friends and Enemies. Second Edition. New York: Routledge.

Szabó, M., Kovács, M., Luu Lan Anh, N., \& Fliszár, É. (2014). A pedagógusok nemi szerepekkel és sztereotípiákkal kapcsolatos nézetei. In Gordon Győri, J. (szerk.), Tanárok interkulturális nézetei és azok hatása az osztálytermi munkára. A multikulturális és interkulturális szemlélet elméleti alapjai és történeti vonatkozásai az oktatásban (pp. 5668) Budapest: ELTE Eötvös Kiadó

Szekeres, Á. (2011a): Enyhén értelmi fogyatékos gyermekek szociális integrációja az általános iskola 4. 5. és 6. osztályában. Doktori disszertáció. Budapest: ELTE-PPK.

Szekeres, Á. (2011b): A szociális kapcsolatok minősége integrált körülmények között - a tanulásban akadályozott gyermekek szemszögéből. In Papp, G. (szerk.), A diagnózistól a foglalkozási rehabilitációig (pp. 73-88) Budapest: ELTE Eötvös Kiadó

Szekeres, Á. (2012): Integráltan tanuló enyhén értelmi fogyatékos gyermekek szociális helyzetének felmérése szociometria segítségével. Iskolakultúra, 11, 3 - 23.

Szekeres, Á. \& Horváth, E. (2014). Enyhén értelmi fogyatékos gyermekeket integráló iskolai osztályok szociometriai jellemzői. Magyar Pszichológiai Szemle, 69 (1), 263-281.

Tuersley-Dixon, L., \& Frederickson, N. (2016). Social inclusion of children with complex needs in mainstream: does visibility and severity of disability matter? International Journal of Developmental Disabilities, 62 (2), 89-97.

Vajda, Zs. (2004). A társas kapcsolatok és viselkedés fejlődése kisiskolás kortól serdülőkorig In Mészáros, A. (szerk.), Az iskola szociálpszichológiai jelenségvilága (pp. 145-161) Budapest: ELTE Eötvös Kiadó. 